\title{
Risiko Keselamatan dan Kesehatan Kerja Pada Pembangunan Gedung Bertingkat Delapan
}

\author{
Muhammad Heri Zulfiara, Qeny Wilana ${ }^{\mathrm{b} *}$ \\ ${ }^{a}$ Program Studi Teknik Sipil, Fakultas Teknik, Universitas Muhammadiyah Yogyakarta \\ ${ }^{b}$ Mahasiswa Program Studi Teknik Sipil, Fakultas Teknik, Universitas Muhammadiyah Yogyakarta
}

\section{Riwayat Artikel}

Diserahkan

1 Desember 2020

Direvisi

4 Januari 2021

Diterima

1 Februari 2021

*Penulis korespondensi wilana455@gmail.com

\begin{abstract}
Abstrak
Proyek gedung adalah salah satu penyumbang angka kecelakaan kerja terbesar di Indonesia, semakin besar proyek yang dibangun, maka semakin besar pula risiko kecelakaan kerja yang dapat terjadi. Oleh karena itu, perlu diperhatikan ketepatan dalam penerapan manajemen risiko yang diambil. Implementasi manajemen risiko dapat dituang dalam bentuk peraturan Keselamatan dan Kesehatan kerja (K3). Di Indonesia, masalah kecelakaan kerja masih terkesan diabaikan, hal ini terbukti dari angka kecelakaan kerja yang masih tinggi. Analisis risiko K3 dilakukan sebagai tolak ukur seberapa aman atau seberapa besar risiko yang mengancam pekerja dalam melaksanakan aktivitas di lokasi proyek. Penelitian ini dilakukan dengan metode kuantitatif, yakni dengan memberikan penilaian/skor pada masing-masing variabel risiko kegiatan berdasarkan matriks risiko yang tersedia. Penilaian dilakukan dengan pengambilan data triplo, yakni dengan tiga narasumber yang kemudian diambil nilai rata-ratanya. Hasil dari analisis risiko Keselamatan dan Kesehatan Kerja (k3) yang telah dilakukan pada kegiatan struktural yakni penulangan, bekisting, dan pengecoran pada balok, pelat lantai, dan kolom di pembangunan Gedung Pusat Riset dan Inovasi Dasron Hamid Universitas Muhammadiyah Yogyakarta ini adalah kategori risiko sedang dengan nilai tingkat risiko rata-rata sebesar 9.

Kata-kata kunci: keselamatan dan kesehatan kerja, gedung bertingkat, risiko
\end{abstract}

\section{PENDAHULUAN}

Di Indonesia, masalah kecelakaan kerja masih terkesan diabaikan, hal ini terbukti dari angka kecelakaan kerja yang masih tinggi. Dilansir dari data Badan Penyelenggara Jaminan Kesehatan (BPJS) Ketenagakerjaan, terjadi sebanyak 114.148 kasus kecelakaan kerja pada tahun 2018 dan 77.295 pada tahun 2019. Pengabaian pedoman Keselamatan dan Kesehatan kerja (K3) dapat menjadi pemicu terjadinya kecelakaan. Maraknya gangguan kesehatan ataupun kecelakaan akibat kerja dapat merugikan banyak pihak, terutama tenaga kerja itu sendiri (Ervianto, 2005).

Dalam suatu pekerjaan konstruksi, keselamtan menjadi bagian penting yang harus diperhatikan secara seksama seperti halnya mutu, waktu, dan biaya (Christina dkk., 2012). K3 dapat diartikan sebagai upaya yang dilakukan guna menjamin keutuhan secara jasmani ataupun rohani pada semua pihak yang terlibat, meliputi melindungi semua pekerja dan pegawai dalam berkegiatan dan meningkatkan taraf produktivitas, menjamin keselamatan setiap individu, memelihara sumber daya secara efisien dan aman. Menurut Tugeha (2018), penerapan $\mathrm{K} 3$ di lapangan sangat berhubungan dengan risiko yang dapat dialami oleh tenaga kerja. Ssemakin baik pelaksanaan manajemen $\mathrm{K}$ 3, maka hasil manajemennya juga akan semakin baik. Oleh karena itu, penerapan K3 diharapkan bisa menjadi priorotas utama dalam peningkatan kualitas manajemen risiko.

Potensi kegagalan atau kecelakaan dalam pelaksanaan konstruksi bisa ditnijau dari segala aspek, mulai dari pelaksanaan teknis, lingkungan sosial budaya, arah politik, lonjakan ekonomi (Zulfiar \& Jayady, 2018). Faktor penyebab kecelakaan kerja yang paling dominan adalah kurangnya pemahaman dan pengetahuan dari pihak yang terlibat mengenai dasar-dasar K3 (Awuy dkk. 2017). Pada era milenial dengan ilmu dan teknologi yang terus berinovasi dan semakin canggih, $\mathrm{K} 3$ adalah suatu hal yang wajib dilakukan dan dipatuhi oleh pihak penyelenggara kerja guna mendorong produktivitas selain menjamin keselamatan dan Kesehatan pekerjanya dari hal-hal yang megancam. Jika manajemen K3 terealisasi dengan baik, maka angka kecelakaan dapat turun drastis (Yuliandi, dkk, 2019).

Penelitian ini bertujuan untuk mengkaji risiko (K3 pada pembangunan gedung bertingkat untuk mengetahui seberapa besar keamanan suatu pelaksanaan proyek konstruksi dan untuk menjadi pedoman dalam 
meminimalisir potensi kecelakaan yang tertuang dalam manajemen risiko $\mathrm{K} 3$.

\section{METODE PENELITIAN}

\subsection{Metode Analisis Data}

Penelitian ini dilakukan dengan metode kuantitatif yakni menggunakan penilaian kemungkinan kejadian dengan menggunakan data numerik, dimana tingkat risiko ditunjukkan dalam angka dari 1-20 (Gambar 1). Penelitian dilakukan pada Gedung Pusat Riset dan Inovasi Dasron Hamid Universitas Muhammadiyah Yogyakarta yang terletak di Jl. Brawijaya, Geblagan, Tamantirto, Kec. Kasihan, Bantul, Daerah Istimewa Yogyakarta. Peta lokasi penelitian ditunjukkan pada Gambar 2. Pada penelitian ini, digunakan dua sumber data, yakni data primer dan data sekunder. Data primer diperoleh dengan melakukan dokumentasi kegiatan yang diamati dan wawancara langsung terhadap narasumber yang berhubungan dengan kegiatan ke lokasi proyek, sedangkan data sekunder diperoleh dari pihak administrasi proyek berupa data pembangunan seperti denah dan tampak. Setelah semua data terkumpul, selanjutnya adalah analisis data dengan mengalikan peluang kejadian dengan dampaknya. Penilaian dilakukan dengan pengambilan data triplo, yakni dengan tiga narasumber yang kemudian diambil nilai rata-ratanya.

Dampak dan peluang dalam analisis risiko kegiatan memiliki rentang nilai dari 1-5 (Tabel 1). Penilaian didasarkan pada observasi yang telah dilakukan dengan mempertimbangkan aspek lingkungan, pekerja, peralatan, dan material.

Tabel 1 Skor dampak dan peluang

\begin{tabular}{cll}
\hline Skor & \multicolumn{1}{c}{ Dampak } & \multicolumn{1}{c}{ Peluang } \\
\hline 1 & Sangat Ringan & Sangat Jarang \\
2 & Ringan & Jarang \\
3 & Sedang & Mungkin Terjadi \\
4 & Berat & Sering \\
5 & Fatal & Pasti Terjadi \\
\hline
\end{tabular}

\subsection{Identifikasi Variabel Risiko}

Dalam analisis variabel risiko, perlu diidentifikasi kondisi risiko, sumber risiko, dan pengaruhnya terhadap pekerjaan (Soputan dkk, 2014). Identifikasi risiko K3 diambil berdasarkan kejadian yang telah terjadi sebelumnya dengan menggunakan Analisis Komponen Utama untuk menghasilkan aspek risiko (Tjakra \& Sangari, 2011). Identifikasi dilakukan dengan analisa

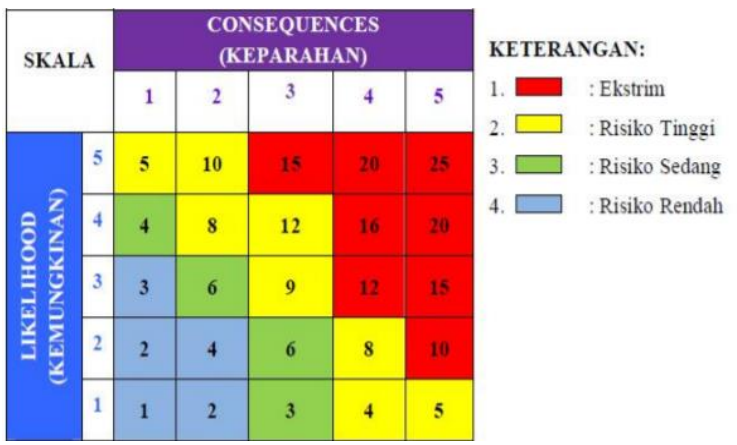

Work Breakdown Structure (WBS) terhadap pekerjaan struktur berikut.

a. Pekerjaan Persiapan dan pemasangan bekisting :

1. Tertimpa scaffolding

2. Terjatuh

3. Tergores pinggiran scaffolding

4. Tertimpa material bekisting

5. Terluka akibat gergaji listrik

6. Terpukul palu

7. Terjepit

8. Tertusuk

b. Pekerjaan Pembesian

1. Terluka ketika pabrikasi besi

2. Tersengat listrik

3. Gangguan pendengaran

4. Tergores

5. Tertimpa material

6. Terjatuh dari ketinggian

7. Terjepit

8. Tertusuk

9. Terperosok ke celah balok

c. Pengecoran

1. Tertabrak truck mixer

2. Tergilas truck mixer

3. Gangguan pernapasan karena debu dari pergerakan truck mixer

4. Iritasi mata

5. Tertimpa material beton segar

6. Tertimpa pipa sambungan concrete pump

7. Terjepit

8. Terperosok

9. Terjatuh

10. Gangguan pernapasan akibat udara yang dikeluarkan beton

d. Pembongkaran bekisting

1. Terpukul palu

2. Tertimpa body bekisting

3. Iritasi mata karena serpihan beton

4. Tertimpa pipa support

5. Tergores pinggiran bekisting

\section{HASIL DAN PEMBAHASAN}

\subsection{Nilai Risiko}

Analisis risiko dilakukan menggunakan metode triplo, yakni pengambilan pendapat melalui wawancara dengan 3 narasumber sebagai acuan. Ketiga data yang diperoleh kemudian dirata-ratakan untuk mendapatkan nilai akhir yang disepakati. Berdasarkan analisis risiko kegiatan persiapan sebagaimana ditunjukkan pada Tabel 1, diperoleh nilai tingkat risiko rata-rata sebesar 9,8. Angka ini menunjukkan jika kegiatan memiliki potensi risiko sedang. Risiko tertinggi adalah tertimpa scaffolding dan terjatuh dari ketinggian. Hal ini dikarenakan proses pengangkutan dilakukan dengan tali, bukan lift pengangkut barang. Jadi ketika tali putus, maka scaffolding sangat berisiko untuk menimpa orang-orang di bawahnya, Adapun peluang besar lainnya yaitu 


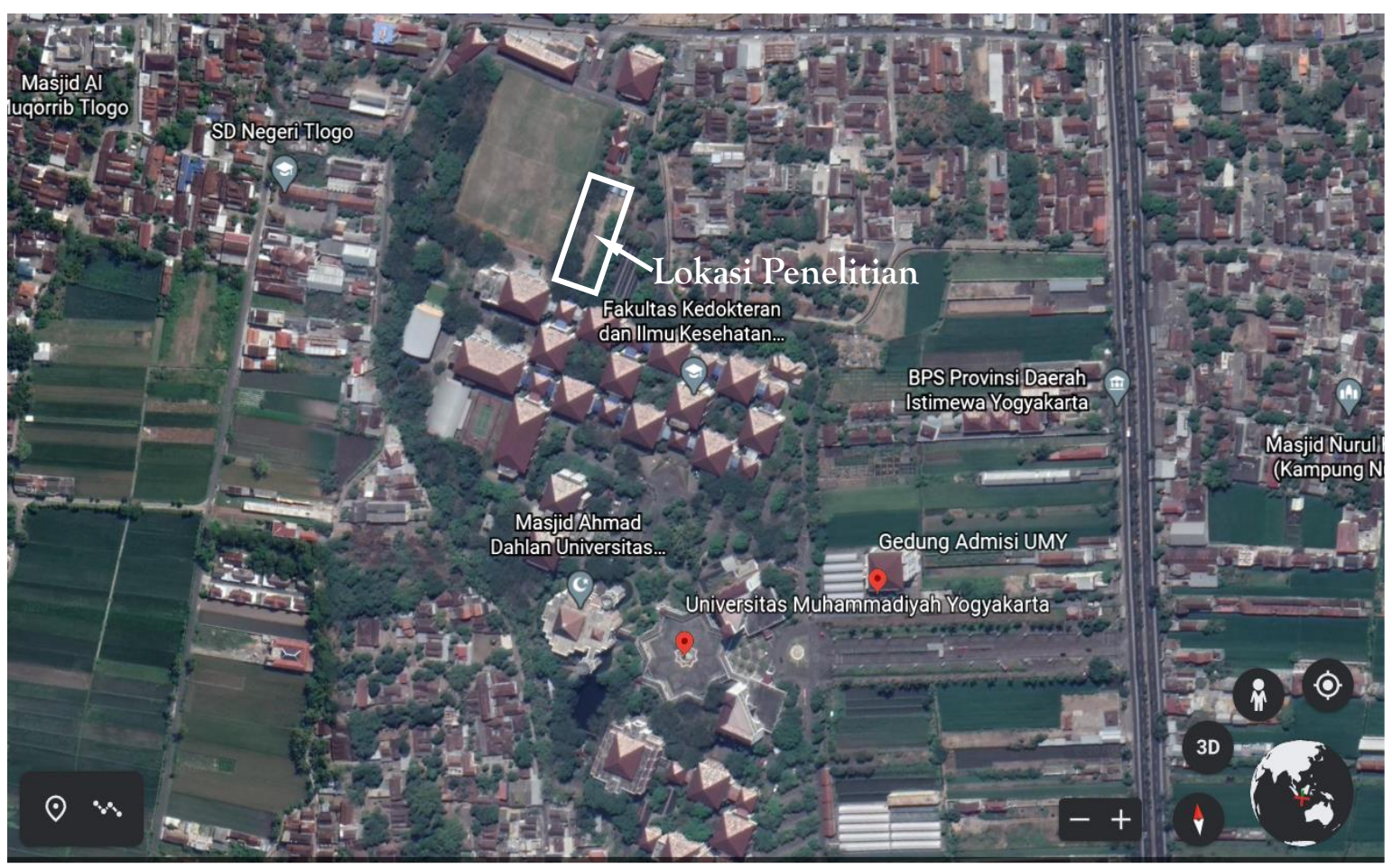

Gambar 3. Lokasi penelitian

Tabel 1. Analisis pekerjaan persiapan

\begin{tabular}{lllll}
\hline No & Potensi Risiko & Peluang (L) & Dampak (C) & Nilai Tingkat Risiko (I) \\
\hline $\mathbf{1}$ & Tertimpa scaffolding yang sedang diangkut & 4 & 5 & 20 \\
$\mathbf{2}$ & Terjatuh dari ketinggian & 4 & 5 & 20 \\
$\mathbf{3}$ & Terluka karena gergaji listrik & 4 & 3 & 12 \\
$\mathbf{4}$ & Tersengat listrik & 2,5 & 2,3 & 5,8 \\
$\mathbf{5}$ & Terjatuh dari mainframe & 3,5 & 2 & 7 \\
$\mathbf{6}$ & Terpukul palu & 2,3 & 2 & 4,7 \\
7 & Tertusuk paku ketika mengangkut body bekisting & 1 & 1 & 1 \\
8 & Terperosok ke tengah balok & 3,3 & 2,3 & 7,8 \\
\hline Total & & & & 78,3 \\
Rata-rata & & $1-4$ & \\
Kategori risiko & $5-11$ & Rendah \\
& & $12-16$ & Sedang \\
& & & Tinggi \\
\hline
\end{tabular}

Tabel 2. Analisis penulangan balok dan pelat lantai

\begin{tabular}{lllll}
\hline No & Potensi Risiko & Peluang (L) & Dampak (C) & Nilai Tingkat Risiko (I) \\
\hline $\mathbf{1}$ & Tangan terluka karena bar cutter & 2 & 3 & 6 \\
$\mathbf{2}$ & Tangan terluka ketika pembengkokan besi & 1 & 2 & 2 \\
$\mathbf{3}$ & Gangguan pendengaran & 3 & 3 & 9 \\
$\mathbf{4}$ & Tersengat listrik & 2 & 3 & 6 \\
$\mathbf{5}$ & Tertimpa material & 3 & 4 & 12 \\
$\mathbf{6}$ & Terjatuh dari lift barang & 4 & 4 & 16 \\
7 & Tertusuk paku ketika membawa material ke & 4 & 3 & 12 \\
& lokasi perakitan & 4 & 5 & 20 \\
8 & Terjatuh dari lokasi perakitan & 2 & 3 & 6 \\
$\mathbf{9}$ & Terjepit & 3 & 2 & 6 \\
10 & Tertusuk tulangan & 3 & 6 \\
$\mathbf{1 1} \quad$ Terperosok ke tengah balok & & & 101 \\
\hline Total & & $1-4$ & 9.2 \\
Rata-rata & & $5-11$ & Rendah \\
Kategori risiko & & $12-16$ & Sedang \\
& & & Tinggi \\
\hline
\end{tabular}

terjatuhnya tukang ketika memasang scaffolding karena tidak adanya pengaman Full Body Harmes.

Analisis risiko terhadap kegiatan penulangan balok dan pelat lantai, diperoleh nilai tingkat risiko rata-rata sebesar 9,2 (Tabel 2). Angka ini menunjukkan jika kegiatan memiliki potensi risiko sedang. Pada analisis, risiko tertinggi adalah terjatuh dari lokasi perakitan. Hal ini dikarenakan perakitan dilakukan di atas gedung tanpa adanya pengaman seperti safety belt atau Full Body Harmes.

Tabel 3 menunjukkan hasil analisis risiko terhadap kegiatan pembesian kolom. Dari Tabel 3, diperoleh nilai tingkat risiko rata-rata sebesar 8,3. Angka ini menunjukkan jika kegiatan memiliki potensi risiko sedang. Pada analisis, risiko tertinggi adalah terjatuh dari 
Tabel 3. Analisis penulangan kolom

\begin{tabular}{lllll}
\hline $\mathbf{N}$ & Potensi Risiko & Peluang $(\mathrm{L})$ & Dampak $(\mathrm{C})$ & Nilai Tingkat Risiko (I) \\
$\mathbf{0}$ & Tangan terluka karena bar cutter & 2 & 2 & 4 \\
$\mathbf{1}$ & Tangan terluka ketika pembengkokan besi & 1 & 2 & 2 \\
$\mathbf{3}$ & Gangguan pendengaran & 3 & 2 & 6 \\
$\mathbf{4}$ & Tersengat listrik & 2 & 2 & 4 \\
$\mathbf{5}$ & Tertimpa material & 3 & 4 & 12 \\
$\mathbf{6}$ & Tertusuk paku ketika membawa material ke lokasi & 4 & 4 & 16 \\
& perakitan & 4 & 4 & 16 \\
7 & Terjatuh dari mainframe & 3 & 2 & 6 \\
8 & Tergores besi tulangan & & & 66 \\
Total & & $1-4$ & 8.3 \\
Rata-rata & & $5-11$ & Rendah \\
Kategori risiko & & $12-16$ & Sedang \\
& & & Tinggi \\
\hline
\end{tabular}

Tabel 4. Analisis bekisting kolom

\begin{tabular}{|c|c|c|c|c|}
\hline No & Potensi Risiko & Peluang (L) & Dampak $(\mathrm{C})$ & Nilai Tingkat Risiko (I) \\
\hline 1 & $\begin{array}{l}\text { Tertimpa bekisting } \\
\text { material }\end{array}$ & 4 & 4 & 16 \\
\hline 2 & Tertimpa bekisting saat pemasangan & 2 & 3 & 6 \\
\hline 3 & Terpukul palu & 3 & 2 & 6 \\
\hline 4 & Tergores pinggiran bekisting & 2 & 2 & 4 \\
\hline 5 & Tertimpa besi support & 3 & 3 & 9 \\
\hline 6 & Terjatuh & 3 & 2 & 6 \\
\hline \multicolumn{2}{|c|}{ Total } & & & 47 \\
\hline \multirow{4}{*}{\multicolumn{2}{|c|}{$\begin{array}{l}\text { Rata-rata } \\
\text { Kategori risiko }\end{array}$}} & & & 7.8 \\
\hline & & & $1-4$ & Rendah \\
\hline & & & $5-11$ & Sedang \\
\hline & & & $12-16$ & Tinggi \\
\hline
\end{tabular}

Tabel 5. Analisis risiko kegiatan persiapan pengecoran balok, pelat lantai, dan kolom

\begin{tabular}{|c|c|c|c|c|}
\hline $\begin{array}{l}\mathrm{N} \\
\mathrm{o}\end{array}$ & Potensi Risiko & Peluang (L) & Dampak (C) & Nilai Tingkat Risiko (I) \\
\hline 1 & Tertabrak truck mixer & 3 & 2 & 6 \\
\hline 2 & Terjepit truck mixer & 2 & 2 & 4 \\
\hline 3 & Terkena debu & 2 & 2 & 4 \\
\hline 4 & Terlindas & 1 & 4 & 4 \\
\hline 5 & Tertusuk/tergores saat uji slump & 3 & 2 & 6 \\
\hline \multirow{2}{*}{\multicolumn{2}{|c|}{ Total }} & & 36 \\
\hline \multirow{4}{*}{\multicolumn{2}{|c|}{$\begin{array}{l}\text { Rata-rata } \\
\text { Kategori risiko }\end{array}$}} & & & 6 \\
\hline & & & & Rendah \\
\hline & & \multirow{2}{*}{\multicolumn{2}{|c|}{$5-11$}} & Sedang \\
\hline & & & & Tinggi \\
\hline
\end{tabular}

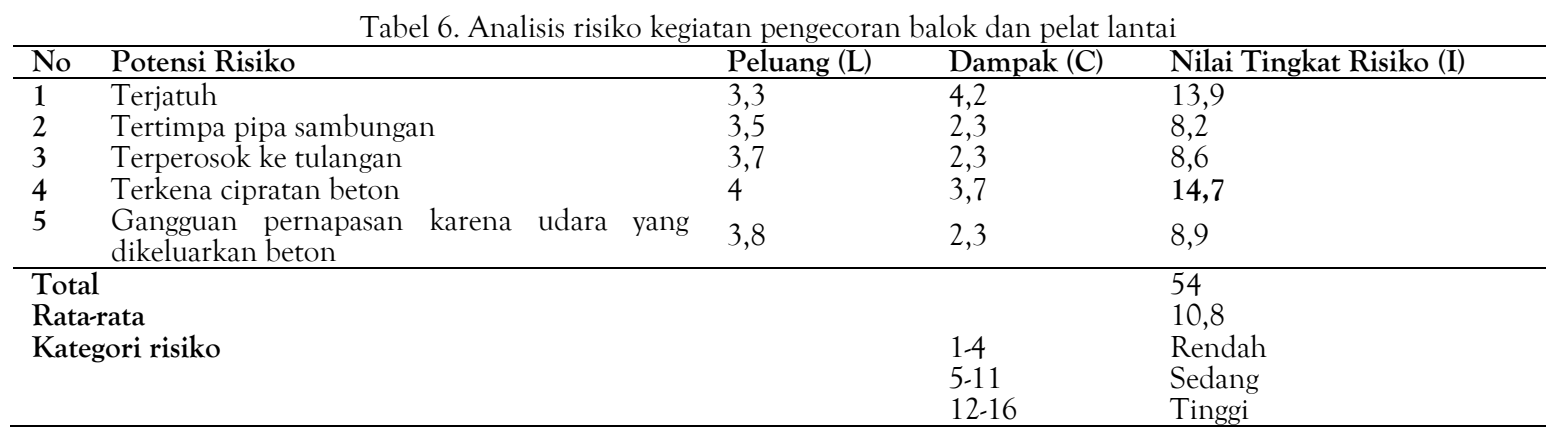

mainframe dan tertusuk paku ketika membawa material ke lokasi perakitan. Hal ini dikarenakan perakitan dilakukan di atas scaffolding tanpa pengaman, jadi sangat berpotensi jatuh. Selain itu, pengangkutan dilakukan tanpa menggunakan alas kaki, jadi sangat rentan tertusuk.

Dari analisis yang ditunjukkan pada Tabel 4, diperoleh nilai tingkat risiko rata-rata sebesar 7,8 pada pekerjaan bekisting kolom. Angka ini menunjukkan jika kegiatan memiliki potensi risiko sedang. Pada analisis, risiko tertinggi adalah tertimpa body bekisting saat pengangkutan berlangsung karena pengangkutan dilakukan dengan tali, bukan lift pengangkut barang.
Dari analisis yang ditunjukkan di Tabel 5, diperoleh nilai tingkat risiko rata-rata sebesar 6 terhadap kegiatan persiapan pengecoran. Angka ini menunjukkan jika kegiatan memiliki potensi risiko sedang. Risiko tertinggi adalah tertimpa pipa concrete pump, hal ini dikarenakan pekerja harus memindahkan pipa berat tanpa pelindung kaki.

Tabel 6 menunjukkan hasil analisis risiko terhadap kegiatan pengecoran balok dan pelat lantai, Hasil analisis menunjukkan nilai tingkat risiko rata-rata sebesar 10,8 . Angka ini mengindikasikan bahwa kegiatan memiliki potensi risiko sedang. Risiko terbesar adalah terkena 
Tabel 7. Analisis risiko kegiatan pengecoran kolom

\begin{tabular}{|c|c|c|c|c|}
\hline No & Potensi Risiko & Peluang (L) & Dampak (C) & Nilai Tingkat Risiko (I) \\
\hline 1 & Terjatuh & 5 & 4 & 20 \\
\hline 2 & Tertimpa pipa sambungan & 4,3 & 2 & 8,7 \\
\hline 3 & Terperosok ke tulangan & 2,3 & 2 & 4,7 \\
\hline 5 & $\begin{array}{l}\text { Gangguan pernapasan karena udara yang } \\
\text { dikeluarkan beton }\end{array}$ & 4,3 & 3,3 & 14,4 \\
\hline 6 & Terpukul palu & 2,7 & 2,3 & 6,2 \\
\hline \multicolumn{2}{|c|}{ Total } & & & 85.8 \\
\hline \multicolumn{2}{|c|}{ Rata-rata } & & & 10.7 \\
\hline \multirow{3}{*}{\multicolumn{2}{|c|}{ Kategori risiko }} & & $1-4$ & Rendah \\
\hline & & & $5-11$ & Sedang \\
\hline & & & $12-16$ & Tinggi \\
\hline
\end{tabular}

Tabel 8. Analisis risiko kegiatan pembongkaran bekisting balok, pelat lantai, dan kolom

\begin{tabular}{lllll}
\hline No & Potensi Risiko & Peluang $(\mathbf{L})$ & Dampak $(\mathbf{C})$ & Nilai Tingkat Risiko (I) \\
\hline $\mathbf{1}$ & Terjatuh dari mainframe & 5 & 2,7 & 13,3 \\
2 & Tertimpa body bekisting & 4,3 & 4,2 & $\mathbf{1 8 , 1}$ \\
3 & Terjepit & 2,7 & 2,3 & 6,2 \\
$\mathbf{4}$ & Tertusuk & 2 & 2 & 4 \\
5 & Terpukul palu & 2,7 & 1,7 & 4,4 \\
6 & Tergores pinggiran bekisting & 4 & 2,3 & 9,3 \\
7 & Terjatuh dari mainframe & 5 & 2,7 & 13,3 \\
8 & Tertimpa body bekisting & 4,3 & 4,2 & $\mathbf{1 8 , 1}$ \\
Total & & & 85,8 \\
Rata-rata & & $1-4$ & 10,7 \\
Kategori risiko & & Rendah \\
& & $12-11$ & Sedang \\
\hline
\end{tabular}

cipratan beton, hal ini dikarenakan tidak adanya sarung tangan dan masker yang digunakan pekerja.

Dari analisis yang telah dilakukan terhadap kegiatan pengecoran kolom (Tabel 7). diperoleh nilai tingkat risiko rata-rata sebesar 10,7. Angka ini menunjukkan jika kegiatan memiliki potensi risiko sedang. Risiko tertinggi yang mengancam yakni terjatuh, hal ini dikarenakan pengecora kolom dilakukan di atas scaffolding ataupun bekisting balok tanpa adanya pengaman ataupun full body harmes.

Tabel 8 adalah hasil analisis risiko kegiatan pembongkaran bekisting balok, pelat lantai, dan kolom, yaitu rata-rata sebesar 9,2, Angka ini menunjukkan jika kegiatan memiliki potensi risiko sedang, Risiko terbesar yang mengancam adalah potensi terjatuhnya pekerja dari main frame karena tidak adanya pengaman. Dari hasil keseluruhan, risiko terbesar ditunjukkan kegiatan pengecoran dan pembongkaran body bekisting (Tabel 9).

\section{KESIMPULAN}

Kesimpulan yang diperoleh dari penelitian mengenai identifikasi dan analisis risiko keselamatan dan Kesehatan Kerja (K3) untuk kegiatan struktural yakni penulangan, bekisting, dan pengecoran pada balok, pelat lantai, dan kolom di pembangunan Gedung Research and Inovation Center of Dasron Hamid Universitas Muhammadiyah Yogyakarta yang terletak di Jl, Brawijaya, Geblagan, Tamantirto, Kec, Kasihan, Bantul, Daerah Istimewa Yogyakarta ini adalah kategori risiko sedang dengan nilai tingkat risiko rata-rata sebesar 9. Kategori risiko sedang menunjukkan jika implementasi sistem manajemen risiko keselamatan dan keksehatan kerja (K3) di lingkungan proyek berjalan cukup baik dan aman.

\begin{tabular}{|c|c|c|}
\hline No & Tinjauan & $\begin{array}{l}\text { Nilai Tingkat Risiko (I) } \\
\text { Rata-rata }\end{array}$ \\
\hline \multicolumn{3}{|c|}{ Persiapan dan pemasangan bekisting } \\
\hline 1 & Balok dan pelat lantai & 9.8 \\
\hline 2 & Kolom & 7.8 \\
\hline To & & 17.6 \\
\hline Rat & & 8.8 \\
\hline \multicolumn{3}{|c|}{ Penulangan } \\
\hline 1 & Balok dan pelat lantai & 9.2 \\
\hline 2 & kolom & 8.3 \\
\hline To & & 17.5 \\
\hline Rat & & 8.8 \\
\hline \multicolumn{3}{|c|}{ Pengecoran } \\
\hline 1 & Kegiatan persiapan & 6 \\
\hline 2 & Balok dan pelat lantai & 10.8 \\
\hline 2 & Balok dan pelat lantai & 10.8 \\
\hline 3 & Kolom & 10.7 \\
\hline To & & 27.5 \\
\hline & & 9.2 \\
\hline \multicolumn{3}{|c|}{ Pembongkaran bekisting } \\
\hline & $\begin{array}{l}\text { Balok, pelat lantai, dan } \\
\text { kolom }\end{array}$ & 9.2 \\
\hline To & & 9.2 \\
\hline Rat & & 9.2 \\
\hline
\end{tabular}

\section{Daftar Pustaka}

Awuy, T, Prastasis, P.A.K, dan Mangare, J.B. 2017. Faktor-faktor Penghambat Penerapan Sistem Manajemen K3 Pada Proyek Konstruksi di Kota Manado, Jurnal Sipil Statik 5(4), 187-194

Christina, W. Y., Djakfar, L., \& Thoyib, A. 2012. Pengaruh Budaya Keselamatan dan Kesehatan Kerja (K3) terhadap kinerja proyek konstruksi. Rekayasa Sipil 6(1), 83-95.

Ervianto, W. I. 2005. Manajemen Proyek Konstruksi Edisi Revisi. Yogyakarta: Andi Offset. 
Ningsih, S. O. D., Hati, S. W. 2019. Analisis Resiko Keselamatan Dan Kesehatan Kerja (K3) Dengan Menggunakan Metode Hazard and Operability Study (Hazop) Pada Bagian Hydrotest Manual di PT. Cladtek Bi Metal Manufacturing. Journal of Applied Business Administration 3(1), 29-39.

Soputan, G. E., Sompie, B. F., Mandagi, R. J. 2014. Manajemen Risiko Kesehatan dan Keselamatan Kerja (K3) (Study Kasus Pada Pembangunan Gedung SMA Eben Haezar). Jurnal Ilmiah Media Engineering 4(4), 229. 238

Tjakra, J., Sangari F., 2011. Analisis Risiko Pada Proyek. Konstruksi Perumahan di Kota Manado, Jurnal Ilmiah Media Engineering 1(1), 29-37
Tugeha, W. P. 2018. Manajemen Risiko Keselamatan dan Kesehatan Kerja Pada Proyek Konstruksi, Jurnal Sipil Statik 6(11), 907-916

Yuliandi, C.D., Ahman, E. Penerapan Keselamatan dan Kesehatan Kerja (K3) di Lingkungan Kerja Balai Inseminasi Buatan (BIB) Lembang. Manajerial: Jurnal Manajemen dan Sistem Informasi 18(2), 98-109.

Zulfiar, M.H., Jayady, A., Saputra, J., Rukmono, N. 2018. Kerentanan Bangunan Rumah Cagar Budaya Terhadap Gempa di Yogyakarta. Jurnal Karkasa 4(1), 5-12. 